\title{
Idiolek van T.T. Cloete
}

Ena Jooste

POTCHEFSTROOM

\section{Abstract \\ Idiolect of T.T. Cloete}

Idiolect in particular has a prominent poetical component. In this article it is shown that this view can be traced back to earlier as well as concurrent statements by Cloete, the critic. It is established that the views of Cloete on the essence and meaning of verse as a literary form of art are reflected in his poetry. He has, for example, stated that the visual elements incorporated in modern artistic texts contribute in an essential way to their meaning. This view correlates strongly with his personal style as a poet and the thematic preoccupation with 'the eye' in Idiolek. Typical aspects of his lexicon are also determined because the repetitive use of certain words is part and parcel of literary idiolect. A résumé of the findings of this article is compared with and corroborated by the reception of Cloete's first four volumes of verse. It is concluded that Cloete's dual role as a poet-critic is complemented by the religious base on which he stands and that these components contribute to the essence and quality of his poetry. In him we indeed have a successful union of instinct, intellect and faith.

\section{Inleiding}

Die artistiek-kreatiewe aanslag van T.T. Cloete se wetenskaplike bydraes en die wetenskaplike toonaard van sy poësie het geen bekendstelling nodig nie. Ook die religieuse inslag van sy digkuns is algemeen bekend. Toe sy vierde digbundel in 1986 verskyn het, het 'n mens dadelik gewonder of jy dalk hier met idiolek en Idiolek in "jukstaposisie" te maak het.

Die titel impliseer reeds dat 'n outeur se persoonlike stempel aan die orde sal kom in die bundel Idiolek. Literêre idiolek staan immers "voor de specifieke individuele eigenschappen die de teksten van de auteur kenmerken" (Dorlijn, 1984:7). Hoewel die digter nie noodwendig met die liriese subjek gelykgestel kan word nie, is die aanname dat Idiolek die kiemsel van Cloete se idiolek kan bevat, voor die hand liggend. Die ervaring het al geleer dat Cloete aspris is met 
sy betiteling van bundels. Ook die rubrisering in hierdie bundel lei 'n mens om na die grootste gemene deler van die Cloete-idiolek in Idiolek te soek, want vanaf "pegasea" tot "holografie" wys die rubriekbetiteling uit na die eie maaksel.

\section{Literator-digter en $\mathrm{i} /$ Idiolek}

Die poëtikale titel, Idiolek, die keuse van bepaalde digters vir toepassings, transkripsies en perifrase en die onbetwisbaar literêre rubrisering in die bundel strook met dit wat 'n mens van 'n literator-digter verwag. 'n Soortgelyke intellektuele procédé is ook die verbandlegging tussen uiteenlopendes of ooreenstemmendes. Soos die praktyk om van en deur ander digters te praat die samehang van die skepping illustreer, demonstreer die praktyk van jukstaponering ook samehange: teenoorgesteld of sinoniem.

By nadere kennis van die gedigte in Idiolek word die interafhanklikheid van Cloete se literator- en digterskap duidelik. Telkens kan die tendense van Idiolek byvoorbeeld herlei word tot 'n verseksteme uitspraak wat voorheen deur Cloete gemaak is. 'n Mens kan selfs 'n "idiolek" uit ldiolek aflei aangesien die bundel 'n neerslag bied van dit wat Cloete se oeuvre tot 1986 gekenmerk het. Aan die hand van Dorlijn (1984:16), wat meen dat die tematiese, foniese, leksikale, morfologiese, sintaktiese en tipografiese aspekte noodsaaklike vertrekpunte is om karakteristieke tendense van 'n idiolek te bestudeer, het die volgende aan die lig gekom:

\subsection{Tematiese aspekte}

Poëtikale besinning keer telkens as grondgedagte terug in Idiolek. Die wisselwerking tussen Cloete se poësie en sy poësieteorie is so heg in hierdie bundel dat die een as aanvullend vir die ander bestempel kan word. Bowendien word die poëtikale besinning in Idiolek keer op keer gekwalifiseer deur 'n baie spesifieke religieuse visie. Digterskap word versekstern gesien as nie vrywillig of willekeurig nie en dit word versintem ondersteun met die gedagte dat die digter "moet stamel / al is dit ook hoe skamel" (Cloete, 1986b:130); die digter "soek" na immanente vorme en is dus (her)skepper. Dit skakel ten nouste met die religieuse visie in die bundel wat aantoon dat die digter sy vermoëns ontvang as 'n "gawe". Tog is dit 'n "aanleg" wat nie die "oorleg" uitsluit nie (Jooste, 1989:66-114).

Die Goddelike wete teenoor die menslike beperkte kenne vorm 'n Leitmotiv in die bundel saam met die kontrastering van die Goddelike en die menslike idiolek. In laasgenoemde verband word veral die Goddelike vormgewing met dié van die mens vergelyk. Die soepele vormgewing en die saambestaan van 
volmaakte en mismaakte vorme tipeer die Goddelike werkwyse teenoor die berekende, strak menslike skeppinge wat soms deur vertekening God na-aap. Die poëtikale diskoers kan sodoende weer eens met die tematiese gesprek van die digter met God verbind word.

Die religieuse gesprek met God hang in Idiolek saam met die gebruik van Bybeltaal en -idioom, maar dit kom dikwels in unieke verband voor, byvoorbeeld vrae wat antwoorde word en antwoorde wat vrae word. Die Bybelgegewe word as 't ware omgedig in 'n eie idioom en Bybeltaal word hiervoor ingespan. 'n Intieme gesprek oor en met God vind plaas en daar word dikwels in terme van die menslike oor God gepraat.

Ontlistorisering van Bybelse gegewe deur parallelle gebruik van Bybelse tyd, ruimte, figure en/of gebeure in aktuele verband is ' $n$ verdere faset van die religieus-tematiese in Idiolek. Soos die parallelle gebruik van Bybeltaal en eie idioom skep dit 'n eie toonaard vir die religieuse in die bundel.

Cloete besin ook versekstern oor digtersdenke en tipeer dit as "droomdenke" wat nie na 'n vae droombeeld verwys nie. Dit word versintern geëkspliseer as "taalskadeloosstelling", "'n vlagie woorde wat die verderf 'n vleugie transendeer" (Cloete, 1986b:78). Met betrekking tot woordbetekenis is Cloete se mening versekstem dat woorde tekstueel beteken en nie reglynig beskrywend is nie. In Idiolek manifesteer dit in die herhaling van woorde en verwante woorde wat betekenisgenererend in semantiese velde optree. So word 'n semantiese veld byvoorbeeld rondom "hand" en "maak" opgebou, waarin die religieuse motief van 'n goddelike Skepper en volmakkte vormgewing uitgebou word totdat uiteindelik sprake is van "die Vorm" (Cloete, 1986b:54).

Die semantiese veld rondom "oog" met sleutelwoorde "sien", "kyk", "ken" en "weet" is verdere aanduidings van die onlosmaaklike verband waarin die poëtikale en die religieuse die bundelinhoud dikteer. "Oog" kan byvoorbeeld uitgewys word as deel van die waamemingskomponent van die literator, sowel as van die digter (Jooste, 1989:118-129).

Nog 'n belangrike poëtikaal-religieuse beskouing wat in Idiolek manifesteer, is die besondere verhouding tussen transkripsie en idiolek. Deur die perifrase van gedeeltelike sitaat of vertalings word Cloete se verseksteme uitspraak (1988c) waar: “... ander digters, ook in die Bybel, kan vir my praat ... Omgekeerd kan ek vir en deur ander praat ..." (vergelyk byvoorbeeld in dié verband die transkripsierubriek in (diolek). Dit wat eie is aan die mens, die digter, God selfs, dit word deur Cloete "getranskribeer". Hierdie toepassing van die eeueoue beginsel van navolging kan getipeer word met Van Dale (1977:164) se tipering van "imitatio", naamlik "navolging met herscheppende pretentie: het 
principe van imitatio is geen bewijs van geestesamoede of gebrek aan inspiratie, maar een waarderend aanvaarden van het overgeleverde". Cloete se kreatiewe transkripsies is veel meer as oorname soos baie duidelik in Idiolek gesien kan word.

'n Laaste eie-aardige tema in Idiolek is die kreatiewe lydenskonsep waarin menslike lyding met die liefde van God gerym word om intertekstueel en religieus Christus as die prototipe van kreatiewe lyding te verwoord: "so word ek genees/ van alle skuld ... as ek doringboom ly" (Cloete, 1986b:100). Dit sluit aan by die digter se "taalskadeloosstelling" en is 'n uitgesproke jukstaponering van die poëtikale en die religieuse.

Op kritiese vlak vind 'n vermenging van die Bybelse, mitiese en die resentaktuele in Idiolek plaas. Die digter satiriseer vleeslikheid, vemietigingsdrang en verloëning van Christus en wy 'n hele rubriek aan "vertekendes". Die digter-skepper verteken in navolging van die Skepper. Die vertekening word egter telkens deur die Christelik-normatiewe en die poëtikale getemper. Ook dít is 'n toonbeeld van die wisselwerkende aard van Cloete se poëtiese, analitiese en religieuse denke.

\subsection{Leksikaal-semantiese en morfologiese aspekte}

Semantiese polivalensie is by uitstek kenmerkend van die taal in Idiolek. Op leksikale vlak getuig die bundel van 'n wye verskeidenheid woorde uit die kunste - veral die musikale en poëtikale - en die mitologie. Die intellektuele en vakwoord asook uitdrukkinge uit ander tale vorm saam met aktualiteite 'n belangrike komponent van die bundel. Tog kom die "gewone woord" in soortgelyke frekwensie voor en word 'n serebrale aanslag gebalanseer.

Om die woordgebruik nog meer kompleks te maak, is daar dikwels tekens van die sogenaamde wilful mistake asook die kundige verwerking van Bybelse en ander erkende uitdrukkings. Betekenis word ook gegenereer deur unieke samestellinge waarin meerduidigheid tot die uiterste ontgin word: as daar nie ' $n$ woord bestaan om ' $n$ bepaalde gedagte mee tot uitdrukking te bring nie, dan skep Cloete ' $n$ woord wat die semantiese inhoud genereer en kommunikeer.

Benutting van die evokatiewe krag van die woord manifesteer ook op die vlak van die vervanging van woorde. Veral in die transkripsierubriek word die tegniek gebruik om die bekende, geantisipeerde woord deur 'n eie woord te vervang wat sy eie assosiasies en implikasies op die semantiese inhoud van die gedig indra. Hierby sluit die omdigting van Bybelse agtergronde aan, waarin vervanging en omstelling gepaard gaan met perifrase om unieke inhoude te genereer. Tematiese inversie word veral uit die transkripsiegedigte duidelik 
asook die verskynsel van semantiese konsentrasie, waardeur 'n bronteksgedeelte op bondiger wyse weergegee word. Hierdie praktyk is die teendeel van perifrasering en word deur Cloete met dieselfde gemak gehanteer.

'n Verdere tendens wat die leser in Idiolek waarneem, is die hoë gebruiksfrekwensie van sekere woorde wat as tematiese wysers van bepaalde semantiese velde in die bundel uitstaan. Dit lei tot die vermoede dat dit moontlik sal wees om ' $n$ bundelleksikon wat met bundeltonaliteit verband hou, saam te stel, en dat dit verder moontlik sal wees om Cloete se eerste vier digbundels vanuit hierdie oogpunt te tipeer.

Die ondersoek skep die moontlikheid om ' $n$ benaderde aanduiding te verkry van die relatiewe prominensie van enkele semantiese velde wat in 'n beduidende mate in al vier die digbundels teenwoordig is. Vir dié doel is die voorkoms van die woordgroepe God/Here, digter/gedig en ly/lyding onderskeidelik geneem as merkers van die rehgieuse, poëtikale en lydensgerigte semantiese velde. Vir elkeen van die vier digbundels is die gebruiksfrekwensie van elk van hierdie woordgroepe bereken as 'n persentasie van die totale gebruiksfrekwensie van al drie die woordgroepe in die betrokke bundel. Die resultate wat met hierdie berekeninge verkry is, is in Figuur 1 voorgestel (kyk die volgende bladsy).

Dit is belangrik om daarvan bewus te wees dat die wyse waarop die gegewens vir verwerking gekies is, slegs toelaat dat hierdie grafieke geneem kan word as aanwysers van die inslag wat die onderskeie semantiese velde in die bundels het. Verder word slegs 'n vergelyking van die relatiewe inslag wat die drie velde ten opsigte van mekaar het, deur die grafiek gegee. Dit is byvoorbeeld geensins regverdigbaar om hiervan af te lees dat ongeveer een derde van die gedigte in Idiolek 'n poëtikale inslag het nie. Wat wel vermoed kan word, is dat die poëtikale veld ongeveer twee keer soveel aandag as die lydensgerigte veld ontvang, omdat die woorde dig/digter twee keer so frekwent as die woorde ly/lyding in hierdie bundel gebruik word. 
Figuur 1: Semantiese veld

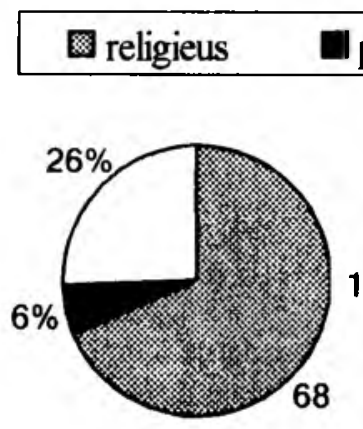

Angelliera

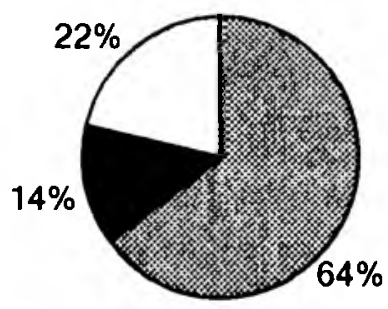

Allotroop

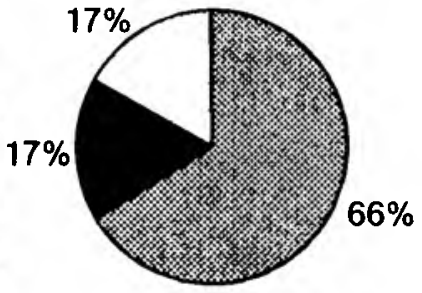

Jukstaposisie

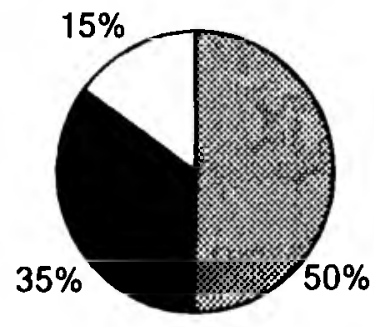

Idiolek

\subsection{Fonies-ritmiese aspekte}

Die teorie van 'n "eie klank" van die gedig (Cloete, 1982a:10) word gedemonstreer in gedigte soos "Van ver en heinde" (Cloete, 1986b:109). Die noue samewerking van klank en ritme is nie alleen tiperend van hierdie gedig nie, maar ook van ander gevalle in Idiolek. Deur interne afwyking van die ritme word in "glasharmonika" (Cloete, 1986b:9) selfs tot die jambiese vers oorgegaan in samewerking met die woordklank (vergelyk "meeste mooiste musiek" waarin die musikale neurieklank [m] herhaal word en 'n andersins ritmiese gedig van 'n metriese versreël voorsien is). 
Ook die wyse waarop die eindrymende verse met behulp van apokoinou en enjambement soms 'n stollende effek in die ritme veroorsaak sodat sleutelwoorde vooropgestel word, is funksioneel en dit word keer op keer deur die herhalende eindrym bevestig. So werk klank, ritme, sintaksis en woordbetekenis ten nouste saam. Die musikale toonaard van Idiolek is juis toe te skryf aan die fonies-ritmiese wat 'n unieke klankgevoeligheid blootlê. Die foniese en ritmiese in die poësie word ook versintern poëtikaal-religieus gespesifiseer sodat Idiolek die digterspraktyk wat sedert Cloete se eerste digbundel voorkom, verklaar en motiveer in die lig van die interaksie van die religieuse en die poëtikale. Uitsprake soos "God laat Hom in in die klank/ van ons taal ..." (Cloete, 1986b:79) en "'n Pols bly aan die werk" (Cloete, $1986 \mathrm{~b}: 109)$ is enkele voorbeelde daarvan.

Semantiese verbandlegging en klankrepetisie, byvoorbeeld deur jukstaponering van horisontale ryme, is saam met die voorkeur vir bepaalde klanke verantwoordelik vir 'n bepaalde bundeltonaliteit. Behaiwe die eie klank van elke gedig is daar ook sprake van dominante klanke in die bundel soos Cloete dit versekstern in die voonitsig gestel het. Die moontlikheid van 'n oeuvretonaliteit kan na aanleiding van die leksikale en fonologiese repetisie in ldiolek ook in Cloete se ander bundels nagegaan word, maar aangesien klank of klankgroeperinge afhanklik is van die konteks waarbinne dit verskyn (Van Gorp, 1984:163), val dit buite die bestek van hierdie artikel.

\subsection{Sintaktiese en tipografiese aspekte}

Die tipografiese groeperinge en sintaksis van die gedigte in Idiolek is besonders. Dit is veral die gevolg van interpunksie- en hoofletterlose versreëls wat in samewerking met die apokoinou en verrassende enjambemente semantiese multivalensie veroorsaak. Hierdie procédě maak 'n appěl op die visuele resepsie van die leser aangesien dit nie ouditief akkuraat waargeneem kan word nie. Dit word beklemtoon deur tipografiese isolasie van strofes, versreëls en woorde wat deur tipografiese wit gereleveer word. Ook die posisionering van sleutelwoorde aan die reëleinde of begin, beklemtoon deur tipografiese wit vooraf, is van die waarneming van die oog afhanklik. Tipograflese superponering deur die vertikale herhaling van klanke of woorde in dieselfde reëlposisie asook sintaktiese parallelisme is soortgelyke visuele beelddraers. Selfs die gebruik van hoofletters om die Here aan te dui, asook tipografies-semantiese relevering soos "Hy IS" is deel van die betekenisdraende bladspieël.

Aangesien die oorwig gedigte in Idiolek geen interpunksie of hoofletters vertoon nie, is die gedigte waarin dit wel gebruik word uitsonderings. Die 
tradisionele begin van 'n sin met ' $n$ hoofletter en afsluiting daarvan met 'n punt kan dus in ldiolek gesien word as afwykings en waar dit voorkom, word die betrokke gedigte betekenisvol gereleveer. Twee opvallende voorbeelde in dié verband is "Nuwe bedeling", waarin 'n epiese struktuur die semantiese inhoud van die titel jukstaponeer, asook "Ballade van die digter".

Enkele gevalle van semantiese ortografering vorm deel van die klem op die visuele. Die opvallendste voorbeeld is waarskynlik die sirkelvormige voorkoms van die [o]-klank. Hierdie klank kom herhaaldelik in woorde voor wat gebruik word in verband met die Goddelike werksaamheid, in die woord "goddelikheid" wat saam met sirkelvormige voorwerpe en "aksies" volkomenheid/ oneindigheid uitspel en woorde soos "rond" en "volop" wat Goddelike volmaaktheid impliseer.

Die volgende verseksterne uitspraak van Cloete (1992:572) komplementeer sy kenmerkende voorkeur vir visuele kommunikasie: "die adekwate verstaan van die teks is van die visuele momente afhanklik". Dit hang saam met sy beskouing dat "die oog anders of beter as die oor die teks simultaan tydvry kan konkretiseer". Ook in sy beskouing en hantering van visuele elemente is poëtiese vermoë en analitiese denke dus komplementêr en dit word in Idiolek aan die hand van die religieuse idiolekties.

\section{Die religieuse dimensie en $\mathrm{i} /$ Idiolek}

Die religieuse dimensie van Cloete se poësie vind ekspliserend neerslag in Idiolek en verdien daarom spesiale aandag. Rede en religie vorm trouens die grondtoon van die verse in hierdie bundel. Dit is eintlik die patroon van die religieus-tematiese denklyn wat in Idiolek eksplisiet aan die orde gekom het wat die navorser met nuwe oë na die verwerking van Bybelse gegewe in Cloete se poësie laat kyk het, omdat dit nie alleen vorige motiewe herhaal nie, maar dit in so 'n mate uitbrei dat 'n eie religieuse kode aantoonbaar geword het. Cloete werk naamlik met 'n oorkoepelende konsep van die grootheid van God teenoor die geringheid van die mens. Die nuwe hiervan is daarin geleë dat die Groot Skepper-kunstenaar teenoor, maar in samewerking met die skepsel-kunstenaar gebeeld word; gevolglik vind die leser 'n deurlopende jukstaposisionele spel. Dit is nie alleen die verhouding tussen skepsel-skepper en God wat 'n besondere kode skep nie, maar die repeterende krag van frekwente gebruik van woorde soos ken, weet, oog en hand in idiolektiese semantiese velde is opvallend. Ondersoek na hierdie idiolektiese woordgebruik is van belang in die dekodering van Cloete se religieuse idiolek. Die hoogtepunt van die kodes wat in Idiolek gemanifesteer het, spel herhaaldelik 'n eiesoortig-religieuse poësie uit waarin ontmoeting van die religieuse en poëtikale plaasvind. 
Cloete transformeer Skrifwaarhede op 'n unieke wyse (vergelyk maar die voorkoms van Bybelse sitaat en perifrase in Idiolek) en bring dit voortdurend in verband met digterskap. Die wyse waarop hy die idiomatiese spreekwyse van die Bybel omdig en gedeeltes van digterlike boeke soos Job en Psalms transkribeer en perifraseer om God as oorsprong van alle verskynsels te erken, eggo die Bybelwoord van Romeine 11:36: "Uit Hom en deur Hom en tot Hom is alle dinge." Dat die grootheid van God en die beperktheid van die mens voortdurend in die sentrum van die beelding bly, terwyl die mens nogtans in intieme verhouding naby God "toegelaat" word, al is dit verwerklik binne 'n lyftaal-lydingskonsep, laat die besondere kwaliteite van die religieuse dimensie in Cloete se poësie dui op 'n "nuwe soort" religieuse poësie. Dit gebeur nie deur gewone onthistorisering van Bybelse gegewens deur anachronismes en satire soos byvoorbeeld by Walters nie, maar veral deur 'n persoonlik-intieme toon van 'n liriese subjek in gesprek met God, waar God nooit tot die menslike gereduseer word nie, maar juis daardeur gereleveer word.

Deur die Bybelse gegewe van 'n skepping wat volmaak deur die Volmaakte geskape is, maar in sy verwording steeds deel van die skepping is, te formuleer in terme van die skepper-Skepper-verhouding, bring Cloete 'n nuwe klank in die religieuse hantering van kreatiwiteit in die Afrikaanse poësie. Baie voorbeelde kan aangehaal word om Cloete se procédé in dié verband met dié van ander digters te kontrasteer, maar genoeg. Die kruks van Cloete se hantering van die Bybelse gegewe lê myns insiens daarin opgesluit dat hy in eie idioom die begrippe volmaakte en mismaakte defimieer as integrale deel van die Skepping en gaandeweg leksikale verbande lê oor gedigte en bundels heen wat woorde 'n eie taal laat praat. 'n Enkele voorbeeld is die woord "laglag" uit die gedig "kwingkwang" (vgl. Jooste, 1989:219).

\section{Transkripsie en i/Idiolek}

Die besondere trek van die bundel Idiolek om intertekstuele gesprek eksplisiet uit te wys deur rubrieke te betitel met "toepassings ..." (Cloete, 1986b:51-54), "transkripsie" (Cloete, 1986b:57-67) en "perifrase" (Cloete, 1986b:71-79), verdien aandag aangesien hierdie rubrieke tot enkodering van idiolektiese verskynsels lei.

Beskou byvoorbeeld die betekenis van die titels van die betrokke rubrieke. Die vraag waarom Cloete juis in Idiolek só rubriseer, terwyl intertekstualiteit reeds sedert sy eerste digbundels onder andere by wyse van titels en motto's gevind kan word in gedigte wat verspreid oor die bundels voorkom, is veral belangrik. Bowendien impliseer "toepassing" dat 'n bestaande beginsel in die digpraktyk gebring word, terwyl "perifrase" dui op uitbreiding van die reeds bestaande. 
Veral "transkripsie" hou verband met die reeds bestaande, aangesien dit weergawe of oorname impliseer - 'n konsep wat nog radikaler in stryd is met die eie of kenmerkende wat deur die oorkoepelende bundeltitel in die vooruitsig gestel word. Transkripsie is immers die oorbring van "(letter)tekens van een tekst uit een bron naar andere tekens waarbij de semiologische functie van de tekens gelijk blijft"' (Janssen, 1984:345).

Met betrekking tot Cloete se idiolek gaan dit nie oor poëtikale invloed of selfs intertekstualiteit as sodanig nie, maar die kenmerkende trekke wat deur die artefak onthul word. In 'n oeuvre vorm sodanige trekke gaandeweg 'n patroon. Die eksplisiete gelyktydige aanbod van die weergawe ("transkripsie") onder die vaandel van die kenmerkende eie ("idiolek") moet juis as gevolg van die paradoksale daarvan skerp onder die soeklig kom. Antwoorde word gesoek op vrae soos die volgende: sluit transkripsie nie die eie oorspronklikheid uit nie? Is dit wel moontlik om deur die bekende iets nuuts te sê? Word daar tematies iets nuuts gesê in hierdie transkripsies of gaan dit om 'n representasie van die oue? Die groot vraag is eintlik: is transkripsie en idiolek versoenbaar en wat is die betekenis van die transkripsierubriek vir die bundel Idiolek?

Uiteindelik kan die belangrike vraag met betrekking tot 'n ondersoek na die literêre idiolek van Cloete saamgevat word met die volgende: hoe kan die feit dat Cloete van vorige prosedures afwyk deur hierdie vorm van intertekstualiteit eksplisiet in Idiolek te rubriseer, ingespan word om tendense in sy idiolek te identifiseer.

\subsection{Uiterlike profiel van "transkripsie"}

Die tien genommerde gedigte in die rubriek "transkripsie" (Cloete, 1986b:5567) volg ' $n$ baie duidelike patroon wat reeds met die titels aangedui word. Die eerste vyf gedigte het Bybeltekste as titels; die daaropvolgende drie het Nederlandse digters se vanne as titels, dan volg 'n enkele Afrikaanse digter se van as gedigtitel. Die laaste gedig in die reeks het 'n "neutrale" titel, wat tog nie so neutraal is nie soos later sal blyk. "Ballade van die digter" (Cloete, 1986b:66) word deur die motto "Werumeus Buning" verbind aan die Nederlandse teks "Ballade van den boer" (Wenumeus Buning, 1935:18-20).

Die taalmedium van die generatiewe tekste van meer as die helfte van die gedigte is dieselfde as dié van die "transkripsies". Die res van die gedigte is vier transkripsies uit Nederlands, 'n taal wat nou verwant is aan die Afrikaans van die "transkripsies", en daarom skyn die konsep, vertaling, nie groot relevansie te hê nie. Vertaling word byvoorbeeld deur Lefevere (1977:22) beskou "as a text written in a well-known language which refers to and represents a text in a language which is not as well known". Bowendien word 
die gedig "Leipoldt" tussen die gedigte met Nederlandse brontekste geplaas, en omdat dít weer 'n Afrikaanse generatiewe teks impliseer, word die vermoede versterk dat daar meer agter hierdie transkripsies skuil as vertaling of reproduksie van die bekende.

Cloete se transkripsies bevat verder nie net spore van die bronteks soos met sy perifrase-gedigte die geval is nie, maar sekere teksgedeeltes word as 't ware gesiteer. Die sitaat word deur Claes (1987:11) getipeer as 'n "identieke transformatie of repetitie". Volgens Claes (1987:11) wysig die gesiteerde transformasie nie betekenisvorm of -inhoud nie, maar dit kom wel in ' $n$ ander konteks as in die oorspronklike voor. Deur 'n transkripsie van 'n titel of motto gebaseer op 'n Bybelteks te voorsien, word die gedig binne 'n sekere toonaard gestel en die eie konnotasies wat deur die transkripsie opgeroep word, neem deel aan betekenisproduksie (vgl. Baetens, 1987:67). Die eksplisiete rubrisering "transkripsie" motiveer dus 'n vergelyking van teksvariante om dié procédé as deel van Cloete se idiolek te identifiseer en te verklaar.

\subsection{Teksvariante en idiolek}

Die aard van die transkripsie-konsep, naamlik dat dit 'n "weergawe" van 'n ander teks is, maak juis wysiginge, wat aangebring mag word, relevant. Generatiewe materiaal kan beskou word as hoogs relevant in die identifisering van literêre idiolek. Volgens Dorlijn (1984:2) bied teksontwikkeling insae in die werkwyse van 'n outeur. Dat 'n studie van teksontwikkeling die betekenis van 'n teks kan verduidelik of dit meer toeganklik kan maak, staan vir Dorlijn (1987:3) vas. Variante as onderdeel van teksontwikkeling, meen hy, kan sekere struktuurprinsipes onthul. Hierdie prinsipes is dan as aktiewe tendense in die ontwikkeling veel duideliker aantoonbaar as in die voltooide werk. Dit is juis veranderinge wat uiteindelik 'n betekenis-gedefinieerde "raam" kan aantoon. Op dié wyse kan die organiserende beginsels wat 'n outeur toepas, sowel as moontlike reëlmatighede op stilistiese, semantiese en tematiese gebied in 'n hele oeuvre getipeer word: "Men krijgt met ander woorden enig zicht op de 'regels' van het literaire idiolect van een auteur" (Dorlijn, 1984:3). Sowel die interne vorm as die voorwaardes waaronder die reëls funksioneer, is moeilik formuleerbaar; daarom verwys Dorlijn deurgaans nie na "reëls" van 'n literêre sisteem nie, maar liewer na "bepaalde entiteiten die verantwoordelijk zijn voor de regelmatigheden die in de teksten van de auteur in kwestie optreden" (Dorlijn, 1987:8). 


\subsection{Opmerkings}

Veral die rubriek "transkripsie" staan in direkte kontras met die Gibbonkarakter (Cloete, 1986a:17) se woorde: "Ek was altyd bang die kritici sou uitvind waar en hoe ek ander digters afgeskryf het in my gedigte ...". Cloete se transkripsies is geensins af- of oorskryf nie, maar die sitaat, gedeeltelike sitaat of vertalings word deurgaans geperifraseer. Die inhoud en vorm van die bronteks word naamlik keer op keer getransformeer deur sintaktiese of tematiese inversie, bondiger formulering of semantiese konsentrasie, aktualisering van die inhoud, tipografiese isolasie van woord, frase of versreël deur kundige aktivering van tipografiese wit, tipografiese superponering deur parallelle sintaksis en 'n kenmerkende klankgevoeligheid en musikaliteit. Die onkonvensionele hantering van die konvensionele eindrympraktyk is veral die gevolg van apokoinou, verrassende enjambemente en jukstaponering. 'n Eie hantering van die jukstaposisietegniek word duidelik uit die gedigte, naamlik die verbandlegging tussen teenoorstaandes of naasliggendes deur vooropstellings. Ten opsigte van hierdie tegniek is veral die sintakties-tipografiese effekte kenmerkend.

Die afwesigheid van hoofletters en interpunksie kom algemeen voor en dit ondersteun die apokoinou-procédé. 'n Enkele geval (transkripsie X) wyk af van hierdie hantering van hoofletters en interpunksie in navolging van die formele elemente wat in die ballade vereis word. Hierdeur word getoon dat dit ook moontlik is om die tradisionele op unieke wyse te perifraseer, en in dié besondere geval veral deur middel van onder andere talryke kenmerkende jukstaposisies.

Die evokatiewe krag van die woord word in Cloete se transkripsies gedemonstreer, veral deur die eie samestellinge, woordtoevoeging en plaasvervangende woorde. Hierby sluit die Bybels-religieuse agtergronde en taalgehruik aan wat hand aan hand met 'n besondere poëtikale besinning gaan. So vind Woord, vers en sin as jukstaponerende komponente van Cloete se idiolek in sy transkripsies neerslag. Dit is die gevolg van 'n bepaalde poëtikale ingesteldheid en religieuse oortuiging wat hy versekstern (Cloete, 1988c) verwoord het met:

Transkripsie raak aan die wetenskaplike van die idiolektiese: dit bring ons terug by dit wat aanleiding tot gedigte gee: ander digters, ook in die Bybel, kan vir my praat in my soeke na die skone, ware, werklike, poëtiese. Dit geld vir elke leser. Ek moet tog namens lesers kan praat. Omgekeerd kan ek vir en deur ander praat: mense en dinge. 
Ook perifrase word hierby betrek. Bowendien onderskryf en beklemtoon Cloete met bogenoemde uitspraak die inherente intertekstuele aard van die literêre, maar met 'n onmiskenbare Christelike stempel daarop. Die lê van verbande in die groot verskeidenheid van die skepping manifesteer dus ook in die transkripsies. Dit wat eie is aan mens (sosiolek), digter (idiolek) en God (Cloete [1988b] verwys ook in 'n gesprek na iets soos 'n teolek - dit wat die Goddelike stempel dra) kan deur die digter gebruik word om sy eie te skep, maar in transkripsies ook om sy eie te illustreer.

Die transkripsiegedigte het 'n eie karakter wat daarvan meer as reproduksie of oorname maak. Transponering van middele waardeur die unieke, nuwe stempel op die bekende afgedruk word, is enersyds tematies en andersyds verstegnies van aard. Die konsep van samehange, wat deur Cloete met behulp van jukstaposisie gekonkretiseer word sodat teenstellendes en ooreenstemmendes verenig word, word weer eens deur die transkripsiepraktyk, soos Cloete dit rubriseer, waar gemaak. Die perifrase van gedeeltelik ooreenstemmende idiolekte moet noodwendig in die bundel Idiolek manifesteer. Die eie konnotasies wat deur hierdie transkripsies opgeroep word, neem deel aan die sogenaamde "betekenisproductie" (Baetens, 1987:63) en die idiolek van die digter is hierby ten nouste betrokke. Kreatiwiteit word dus nie ingeboet nie maar juis ingespan. Die transkripsies vestig enersyds die aandag op 'n idiolek, en aktiveer andersyds 'n nuwe idiolek. Transkripsie is daarom 'n onmisbare deel van 'n digbundel met die titel Idiolek.

\section{Tendense en $\mathbf{i} /$ Idiolek}

Tendense van Cloete se poësie wat sedert Angelliera geresepteer is deur resensente en studente kan verifieer dat Idiolek as astrak van Cloete se idiolek getipeer kan word. Met behulp van 'n lys resensies, verhandelings en proefskrifte wat oor Cloete se poësie handel, was dit moontlik om 'n bestekopname te maak.

Die sistematisering van hierdie groot hoeveelheid uiteenlopende gegewens het uiteindelik sekere deurlopende tendense in Cloete se oeuvre aan die lig gebring. Die aard van die informasie wat hierdeur bekend geword het, het die sistematisering daarvan gedikteer en die volgende bespreking het ten doel die relevering en veralgemening van resultate wat uit Idiolek verkry is.

Die gegewens word in onderafdelings saamgevat aan die hand van onderwerpshoofde wat gekies is volgens dit wat in die resepsie van die bundels die meeste besprekings ontlok het. Behalwe die releverende waarde van so 'n bespreking, het dit ook 'n sistematiserende funksie ten opsigte van verspreide opmerkings in verband met Cloete se idiolek. 


\subsection{Titels en temas}

Die "droomdenke" wat "oorleg" insluit, is nie net in Idiolek aantoonbaar nie, maar die stem van die literator is reeds sedert sy debuutbundel Angelliera in Cloete se poësie hoorbaar. Die resepsie van sy bundeltitels toon hoe dit as literêr ervaar en as intellektueel getipeer word. Pretorius (1981:77) skryf van sy debuutbundel: "die fassinerende, enigmatiese titel Angelliera, laat geen twyfel nie dat die maker 'n vakman, 'n ingewyde is in die kuns van die woord". Ook die titel Jukstaposisie val in hierdie kategorie en is, volgens Spies (1983:11), "'n literêre term wat die leser van aanvang af instel op 'n digter wat hiperwoordbewus is". Dit wat in Idiolek ten opsigte van rede of intellek aantoonbaar is, is 'n sprekende bewys daarvan. Roos (1983:6) wys ook met Jukstaposisie daarop dat "die bundeltitel se sleutelbetekenis geëggo word" in verskillende "wetenskaplike" gedigtitels soos "Simbiose", "Dubbelster" en "Diskant".

Hoewel Jukstaposisie slegs Cloete se tweede digbundel is, verwys Van Zyl (1983:10) na "die ontwikkeling van 'n onnabootsbare idiolek wat ' $n$ mengsel is van nugter beredenering, streng vormgewing en 'n gevoelige belewing van die Skepping in al sy wondere". Hierdie "gevoelige belewing" vind in Idiolek veral neerslag in die integrasie van die digterspraktyk as deel van die goddelike skepping, terwyl 'n unieke kreasiekonsep tot stand gebring word.

Allotroop, Cloete se derde digbundel, het weer eens volgens kritici 'n wetenskaplik-literêre allure. "In Allotroop sal ons verwag: 'n stylfiguur, 'n taalwending waarin telkens 'ander vorme van dieselfde substansie' aan bod kom. Eenderse andershede", sê André Brink (1985:17). Dis hierdie "eenderse andershede" wat in Idiolek in die besondere besinning oor transkripsie manifesteer. Weer eens is dit die meer algemene van vroeër wat die groeipunt van die poëtikale bevat het, wat neerslag vind in 'n geformuleerde poëtikale besinning in Idiolek. Hambidge (1985:13) interpreteer die titel Allotroop nie alleen as verwant aan die chemiese verskynsel 'allotroop' waar sekere elemente in meer as een vorm kan optree nie, maar verbind dit ook met die bekende term "troop" wat in literêre terme dui op "Figures of thought: meaning 'turns' or conversions in which words are used in a way that effects a decided change or extension in their standard meaning." Gräbe (1985:6) sien die titel Allotroop soos sy voorgangers Angelliera (1980b) en Jukstaposisie (1982) as “'n karakteristiek in die kleine van Cloete se (poëtiese) kyk op die werklikheid". Tog gaan Cloete volgens Gräbe (1985:6), in vergelyking met die vorige bundeltitels, in Allotroop "'n stap verder: uiteenlopende sake is nie slegs interafhanklik of komplementerend nie, maar is inderdaad herleibaar tot dieselfde grondvorm - 'n aanname wat in hierdie bundel die sekerheid van 'n feitelike gegewe verkry weens die aanspraak op wetenskaplike bewysbaarheid 
wat deur die titel in die vooruitsig gestel word". Gräbe praat daarom van Cloete se bundelbetiteling wat "as 't ware met voorbedagte rade uitgesoek" word.

In dieselfde trant beskryf Hambidge (1985:9) hoe die herhaling van temas en die verspreiding van gedigte wat oor dieselfde onderwerp handel in Allotroop "telkens vanuit 'n nuwe perspektief bekyk" word "om die wonder van die kreatiewe proses te besing". Sy beskryf ook hoe die bundelindeling "dui op 'n selfbewuste digter wat orden". Juis die bewuste ordening van Idiolek in rubrieke wat eksplisiete poëtikale duiding het, is 'n kristallisasie van vroeëre vingeroefeninge soos dié in Allotroop. Die verwysing in 'n Engelse dagblad (Botha, 1985:13) na Allotroop as "masterly conceived by an erudite mind who seems to know all the tastes of the connoisseur" geld ook van Idiolek. Met Idiolek wys die bundeltitel in Hambidge (1985:10) se terme "semioties" vooruit na die "ek se kyk op sake" en die "persoonlike ars poëtika". Dit wat volgens Hambidge hier aan die orde kom, is op ondubbelsinnige wyse binne 'n eie religieuse denkkader op die digterlike betrek.

Die poëtikale besinning wat so sterk figureer in Idiolek word sedert Angelliera in Cloete se oeuvre geresepteer. In Angelliera se slotgedig "kom die digter se visie op taal en gevolglik ook op poësie" volgens Swanepoel (1981:62) tot uitdrukking en hy bestempel dit as "religieus". In 'n doktorale proefskrif beskryf Venter (1988:67) hoe 'n gedig soos "Rotsode" in Jukstaposisie "die fokus op die digter en die ontstaanswyse van die poësie plaas". Venter (1988:106) sê tereg dat die eerste afdeling van Jukstaposisie ons onder die indruk bring van "'n gesofistikeerde spreker, wat sake uit 'n kunsteoretiese perspektief besien".

Die beginsel van jukstaposisie is van meet af aan deur oplettende resensente in Cloete se poësie waargeneem - reeds voor die tiperende bundeltitel Jukstaposisie. Pretorius (1981:78) noem die gedigte in Angelliera "'n soeke na 'n sinvolle samehang van oënskynlik disparate verskynsels" en sy noem titels van gedigte wat daarop dui, onder andere "correspondances" en "saamhorigheid". Na Pretorius (1981:79) se mening vind ons in Angelliera 'n "saamrym van ongerymdhede" en ontdek Cloete "correspondances" deur middel van skerp waarnemingsvermoë en ryke verbeeldingskrag. Ook Gräbe (1981:69) noem as kenmerk van Angelliera dat "'n poëtiese verband ontdek word tussen oënskynlik willekeurige temas" en deur die gedig "Angelier" te ontleed, kom sy tot die gevolgtrekking dat die bundeltitel eintlik die volgende beteken: "in 'n volmaakte geheel word teenpole saamgevoeg". "Poësie van verskeidenheid en verband" noem Swanepoel (1981:53) hierdie verse. 
Dit is inderdaad wat in Idiolek aangetoon kan word. Die verskeidenheid het veral hier saamgevloei in die verband van jukstaponerende religieuse en poètikale motiewe. Dit is weer eens die praktyk van jukstaponering wat Nienaber (1983:56) "die patentmerk Cloete en kie" noem en omskryf as die byeenplasing en ooreenskuiwing van sake wat nie gewoonlik saamgedink word nie "om 'n kompakte en tegelyk welluidende resultaat te lewer".

Na die verskyning van Allotroop (1985) maak Gilfillan (1985:18) melding van Cloete se "ingesteldheid op variasies". Gilfillan resepteer daarmee saam "'n wending, 'n verowering, 'n bevrydende nuwe insig ... . Die verwoording van 'n ervaring is ook 'n allotroop van die ervaring in sy voor-taal-stadium. Maar so 'n verwoording beteken nie net verligting nie, dit hou ook in dat die twee vorme nie identies is nie. Die verwoording beteken ook 'n verdraaiing - soos wat allotropie in die plantkunde dui op 'n plant wat anders gedraai is".

Met dié poëtikale inhoud van die titel Allotroop is die weg dus berei vir Idiolek se "vindingryke toepassing deurgaans van die beginsel van jukstaposisie wat vroeër reeds so prominent in Cloete se werk gefigureer het: moontlikheid teenoor werklikheid, skepping naas na-skepping, duplikasie, transkripsie, perifrase, teks teenoor teks - 'n manier van kyk wat die basis vorm van Cloete se metaforiek en bepalend is vir die aard van sy vers" (Grové, 1986:8). In ldiolek word die kenmerkende jukstaponerende kyk van Cloete ook poëtikaal gevarieer en gekwalifiseer. Die simbiotiese bymekaardig van poëtiese arbeid van verskillende digters en Bybelse outeurs word in Idiolek benoem deur rubriektitels soos: "toepassings van dante", "transkripsie", "perifrase". Die "transkripsie"-rubriek word deur Pretorius (1987:34) getipeer as 'n afdeling "waarin die idiolekte van verskillende mense en die spraak van God telkens inspraak het in "die taal van die digter". Die "soeke na 'n sinvolle samehang van oënskynlik disparate verskynsels" (vgl. Pretorius oor Angelliera) en die "saamdink" daarvan en "verwoording" wat neerkom op "verdraaiing" (vgl. Gilfillan oor Allotroop) het uiteindelik in Idiolek poëtikaal gekwalifiseer geraak as 'n eie werkwyse, deel van 'n idiolek.

Twee belangrike insigte in dié resepsie van Jukstaposisie geld ook vir Idiolek: "dit gaan waarskynlik eerder om 'n versoening en saambring van jukstas as 'n uiteenlopende naasmekaarbestaan daarvan" (Gräbe, 1984:53) en "Cloete plaas sy digwoorde bewustelik in jukstaposisie met dié van ander digters en demonstreer so die saamhorigheid van hierdie kunstenaars van verskillende tye, verskillende tradisies, verskillende tale" (Pretorius, 1984:79). Versekstern motiveer en formuleer Cloete (1988d:1) sy jukstaponeringspraktyk só: "Ek moet die Skepping nie enkelvoudig belewe nie, ek moet hom as 'n verskeidenheid belewe, en ek moet in hierdie verskeidenheid 'n eenheid probeer 
vind." Volgens Pretorius (1984:85) demonstreer Cloete deur die jukstaponering van twee tekste (die bronteks en die transkripsie/perifrase) in Allotroop dat die "jukstaposisie van die kreatiwiteit van die digter en die aanvullende kreatiwiteit van die leser noodsaaklik en onmisbaar is vir die begryp van literatuur". Deur transkripsie op só 'n wyse te ontvang, word die idiolektiese lê van verbande en samehange deur Cloete selfs verder uitgebrei as die digter se waarneming omdat ook die leser betrek word. Gräbe (1985:6) se lesing van Allotroop sluit hierby aan en sy meen: "die rangskikking van die gedigte in die bundel vergemaklik intergedigtelike verwysing en noop die leser om op die spoor van verskeie variasies insig te verkry in die onderliggende gemeenskaplike essensie binne 'n verskeidenheid van poëtiese manifestasies".

Met "transkripsie" in Idiolek skryf die digter in der waarheid versintern voor hoe sy gedigte gelees moet word. Die Harold Bloom-gedagte van "misreading" (Bloom, 1973:30) word by Cloete geïntegreer in poëtikaal-religieuse besinning en dit is by uitstek aantoonbaar in Idiolek. Hambidge (1986:10) sien ook die eerste rubriek in Idiolek as spesifiek die digterlike wat allotropeer: "die digterlike persoonlikheid neem 'n veelheid van vorme aan. Menslike ordening (en hiermee inbegrepe: digterlike beheer) word teenoor die kosmiese gang geplaas." Hambidge verwys ook na 'n "sterk persoonlike kyk op sake" in die derde afdeling van die bundel en hoe die digter "telkens besig is om ander digters te herinterpreteer, selfs te verwring". Idiolek formuleer naamlik religieus-poëtikaal wat in Cloete se vorige bundels dikwels geïmpliseer is.

Pretorius (1987:35) lees en tipeer raak as sy sê:

In "Vivaldi", die slotgedig van Idiolek, vind ons 'n verbluffende integrasie van talle sleutelmotiewe in die bundel en 'n demonstrasie van sekere aspekte van Cloete se onkonvensionele, idiosinkratiese taalgebruik en styl ... . Intratekstualiteit is een van die opvallendste aspekte van Cloete se digterlike oeluvre.

Juis hierdie eienskap van Cloete se poësie word verwoord deur die rubrisering van "transkripsie".

'n Laaste deursurende tematiese lyn wat in Cloete se poësie reeds sedert Angelliera waargeneem is, is die skepsel-Skepperverhouding. As tema vir die debuutbundel resepteer Spies (1983:11): "God voorsien vir die mens die heelal: Hy is 'bedrywig' met nukleone maar Hy hoor die prewelende, biddende mens." So 'n tipering van 'n digtersperspektief dui nie alleen op die menslike terme ("bedrywig") wat gebruik word om die Goddelike te beskryf nie, maar dit sien ook raak hoe die "geringheid" van die menslike teenoor die almag van God deel is van hierdie poësie. Hierdie religieuse perspektief is die stramien van die 
tematiese realisering in Cloete se gedigte en dit beïnloed enige onderwerp waaroor dit handel, soos Spies aantoon: "As mens weet dat die Here God is, kan jy alles wees - sensueel, ironies, speels, ernstig" en sy tipeer dan ook Angelliera as "Godgesentreerde poësie wat binne die paradoks van geloof en taal mensgesentreerde poësie - in die terminologie van Cloete 'Homosentrie' word." Met die gedig "Homosentrie" as sprekende voorbeeld is dit vir Visagie (1986:240) duidelik dat "die gedagte dat die mens die aarde van God ontvang het en dat God hom steeds toelaat om hierdie wêreld te bewoon", na vore kom uit Cloete se poësie (my kursivering - EJ).

'n Ontmoeting van die religieuse en die poëtikale is reeds in aansluiting hierby uit Angelliera af te lees. Dit word versterk deur die verwerking van Bybelse materiaal wat ook in Jukstaposisie sigbaar is. Pretorius (1984:85) praat byvoorbeeld van die digterswoord en Bybelwoord wat in jukstaposisie geplaas word deur Cloete se kreatiewe verwerking van die Bybelse gegewe. Pretorius (1981:79) beskryf hoe in Angelliera Bybelse teksgedeeltes in gedigte as grondstof gebruik word en hoe besin word oor die aard van die verhouding "mens : heerlikheid van God se skepping" en die verhouding "volk van God : God". Daarby lees Pretorius (1981:81) uit die "verspreide gedigte" wat die erotiese as "kerngegewe" het "'n duidelike morele insig af", naamlik die "ekstatiese vreugde en skeppende krag" van die seksuele binne "omheinde ruimte" soos die huwelik teenoor die "leegheid" van blote sinsgenot.

Soos Cloete se religieuse perspektief sanerend werk ten opsigte van die erotiese, word ook sy satiriese verse in Angelliera (seker sy digbundel met relatief die meeste satires) deur die religieuse perspektief getemper. Gräbe (1981:77) vind in die gedig "Vakansiegangers" blyke van "Goddelike benadering", ten spyte van die menslike selfgenoegsaamheid wat gesatiriseer word, en beskou dié gedig as "'n deurdagte deurtastende deurgronding van die blinde sinloosheid van die selfgenoegsame menslike bestaan, wat nogtans sin het binne 'n Goddelike bestel". Hierdie satire word daarom méér as kritiek op menslike afvalligheid; dit word volgens Gräbe 'n besinning oor "menslike bestaan en Goddelike wil".

Die gegewenheid van menslike vormende vermoë wat reeds in Angelliera as 'n "ontvang" en 'n "toelaat" waargeneem is, en in Jukstaposisie gekontinueer word (vgl. Visagie, 1986:124) vind neerslag in Idiolek waar die gawe spesifiek op digterskap betrek word en die Gewer as Vormgewer op 'n idiolektiese wyse gebeeld word (vgl. 3 hierbo).

Ten slotte is die kreatiewe lydingskonsep, wat so duidelik in Idiolek as "lyftaal" by die digter betrek word, 'n konsep wat in 'n mate reeds voorheen in Cloete se 
poësie geresepteer is. Van der Walt (1987:10) vang die klem op mens en skuld en dood in Angelliera op. Hy voer dit terug na die Bybelse oorsprong "dood waar is jou angel". So sluit dit aan by Gräbe (1981:74) se lesing van "siekte", "dood", "pyn" en "aftakeling" of "verganklikheid" as angel-begrippe. In Allotroop, wat van al die digbundels van Cloete waarskynlik die motiewe pyn en dood die deurlopendste ontgin, beskou Grové (1985:8) Cloete se vormbewussyn, sy hoogs ontwikkeldheid en intellektuele skeppingsvermoë as rede waarom "verse wat so deur pyn en gemis oorheers word" nie in "neulerigheid en patos" ontaard nie. Die gevolgtrekking waartoe Gilfillan (1985:18) kom, is: "in die ervaring van pyn word die bewussyn vir Cloete opgeskerp en is daar bevryding deur dit te vertaal". Gilfillan brei verder hierop uit: "met sy bewustelike 'lipkramp', sy beswering van pyn ('kramp') word ook die lydende kunstenaar tot 'n bevryder ...". Behalwe die idee van kreatiewe pyn wat hier ter sprake kom, kom die "taalskadeloosstelling" van Idiolek onwillekeurig by mens op. Weer eens is dit ' $n$ eksplisiete formulering van digterlike werksaamheid in terme van 'n spesifieke religieuse visie. In plaas daarvan dat die lyding "die kunstenaar beperk", ontwikkel die "verlossende perspektief". Dit alles is geïntegreer in Cloete se religieus-poëtikale verwoording daarvan in Idiolek, wat benewens sy jukstaposisie- en transkripsiepraktyke ook die lydingsmotief positiveer as die kreatiewe op grond van die kreatiewe lyding van Christus vir die sondes van die mensdom.

Aan die ander kant stel Cloete (1988c:14) versekstem dit self só:

Ek kan vir Grieta ly. Is dit nie die basis van die hele Christelike geloof nie? Dat Christus vir ons gely het? So kan ek in elke gedig wat ek skryf vir ander of iets anders lewe. Ek meen dat dit die hele uitgangspunt is van my digkuns ... Ek het goddelike inspraak in ander mense, in ander dinge, in plante, in diere en klippe.

Cloete (1988c:14) verwys ook na die gedig "tong" in Idiolek en sê: "Tog kan ek met hierdie stuk vlees substansie gee aan God en die goddelike. Dit word van my verwag." Dit verklaar die toenemende religieuse toonaard van sy poësie: dit is vir hom 'n roeping om met sy gawe God te verkondig. As Cloete se religieuse besef met die uitspraak van Grové hierbo gerym word, is vers, sin en Woord onbetwisbaar in jukstaposisie in Cloete se idiolek, soos wat dit uit Idiolek ook afgelei is.

\subsection{Die fonies-ritmiese tendense}

Cloete se poësie is sedert sy eerste bundel geresepteer as "poësie met 'n sterk liriese inslag, met 'n fyn ontginning van klanklike en ritmiese effekte" (Swanepoel, 1981:53). In 'n interpretasie van die titel Angelliera sê Pretorius 
(1981:83): “Lier-spel is klankspel - 'n spel van klank en weerklank. Cloete se siening van eenheid en samehang deurdring ook die klankstruktuur van sy gedigte." Gräbe (1981:73) beskryf Cloete se werkwyse met klank, naanılik dat die "rym uiteenlopende dinge laat saamklink".

Dis egter nie alleen die debuutbundel nie, maar ook die tweede een wat kommentaar oor Cloete se besondere hantering van die ritmies-foniese ontlok. Pretorius sowel as Gräbe skryf artikels wat dié aspek van Cloete se procédé belig. Pretorius (1984:79) verwys na die "klankdenke" in Jukstaposisie en maak melding daarvan dat Cloete "die uiters suggestiewe klank-ritmiese rykdom van die Afrikaanse taal" in dié bundel "demonstreer". Gräbe (1984:35) bespreek op haar beurt die "klankeksploitasie" in Jukstaposisie en beweer onder andere: "Dit is duidelik dat daar 'n noue samewerking tussen ritme en klank by Cloete te bespeur is - sowel horisontale as vertikale klankbindinge het 'n beduidende invloed op die ritmiese strukturering van sy poësie. Dit is verder duidelik dat die ritmies-klankmatige strukturering in Cloete se poësie getuig van 'n geraffineerde variasie van sowel konvensionele as oorspronklike procédés." Een van hierdie konvensionele werkwyses van Cloete is sy volgehoue gebruik van eindrym, wat "verrassend gevarieerd en uitermate funksioneel" aangewend word (Gräbe, 1984:25). Visagie (1986:245) wys daarop hoe Cloete se gebruikmaking van eindrym "grootliks van die ander digters uit die sestigerjare en daama" verskil omdat hulle "meestal glad nie van eindrym gebruik maak nie". Nietemin gebruik Cloete hierdie tradisionele ordeningsmetode konsekwent en vind dit, saam met die funksionele vertikale en horisontale ryme, ook neerslag in Idiolek.

Ten opsigte van rym in die algemeen is dit ook in Jukstaposisie vir Gräbe (1984:46) duidelik dat "al die faktore wat rymdigtheid ('rhymedness') bepaal" 'n "integrale deel van Cloete se hantering van klankeffekte" is. Voorbeelde daarvan is ook in Idiolek volop aantoonbaar (Jooste, 1989).

Sterk semantiese verbande word in Cloete se klankontginning geresepteer en sy gebruik van eindrym word dikwels in verband gebring met ooreenstemmende en teëstellende woorde. Die praktyk van jukstaponering word deur Pretorius (1984:81) beskryf as "'n spel met kontrasterende en analoë klankelemente waardeur betekeniskonnotasies geskep word wat weer die begripsinhoud van woorde intensiveer". Pretorius dui ook aan hoe klank en betekenis mekaar releveer en ondersteun. Die maksimale benutting van volrym in die eindrymposisie "om betekenisassosiasies as 't ware klankmatig op te roep" (Gräbe, 1984:46) kan ook hiermee in verband gebring word. 
Dit is opvallend hoe die kommentaar van resensente op die fonies-ritmiese in Cloete se poësie afneem namate klem op die semantiese sterker word. Te oordeel aan die resepsie van Cloete se poësie het die semanties-leksikale gaandeweg meer en meer aandag opgeëis totdat dit uiteindelik in Mukarovsky se terme as kristallisasiepunt in Idiolek geresepteer kan word. Grové (1986:8) verklaar byvoorbeeld van Idiolek.

Dis 'n vers wat, hoewel hier meermale na musiek verwys word, nie daarop uit is om die leser musikaal-ritmies of klankmatig te bekoor nie. Veeleer is dit 'n vers wat met 'n verskeidenheid tegniese middele (onder meer die lê van verbande, die enjambemente en die daaruit voortvloeiende spanning tussen versreël en sin, die swewende cesuur) die leser tegelyk intellektueel stimuleer en beeldend ontroer.

Dít wat reeds in Allotroop deur Gilfillan (1985:18) geresepteer is, naamlik dat die bundel "'n geleerde bundel, maar terselfdertyd 'n eenvoudige bundel" is, word dus in Idiolek geïntensiveer. Terwyl die rym nog steeds "ruggraat" gee aan die "oënskynlik vrye gedig" (Viljoen, 1983) is die foniese ondergeskik aan die leksikale en sintakties-visuele in hierdie bundel. Die swaartepunt het met Idiolek inderdaad verskuif vanaf klank as "rigtingwyser" in die toeganklikheid van Cloete se poësie in Jukstaposisie (Gräbe, 1984:51) tot die leksikaalsemantiese.

Juis omdat interpretasie in Idiolek ten nouste met betekenisproduksie in semantiese velde saamhang, het dit die aandag gevestig op die moontlikheid om 'n kernwoordeskat van gebruikswoorde in Cloete se oeuvre saam te stel en vergelykenderwys te ondersoek. Ongeveer 600 woorde is vir hierdie doel geïdentifiseer en die gebruiksfrekwensie daarvan is in die vier bundels Angelliera, Jukstaposisie, Allotroop en ldiolek bepaal (Jooste, 1989). 'n Grafiese voorstelling van die relatiewe gebruiksfrekwensie van agt tiperende woorde/woordgroepe wat met hoë frekwensie in hierdie vier digbundels voorkom, word in Figuur 2 voorgestel.

Soos die verhoogde klem op leksikale eksploitasie in Idiolek 'n sleutel tot Cloete se oeuvre bied, word die eksplisiete verwysing na die visuele in Idiolek 'n instrument in die enkodering van Cloete se digterspraktyk. Die onkonvensionele vertraging wat dikwels deur enjambement in sy verse veroorsaak word, is in 'n groot mate afhanklik van die leser se interpreterende oog (Gräbe, 1984:34). Gräbe verduidelik ook hoe die laaste rymwoorde in 'n versreël oënskynlik finaal kan voorkom sodat die "sintaktiese voltooiing daarvan in die volgende reël as 'n verrassing ervaar word". Die rymwoord het om hierdie rede 'n "dubbele verwysing", naamlik "retrospektief na die woorde 
binne die vers waarin dit voorkom; prospektief na die sintaktiese snit in die volgende vers waarbinme dit eintlik tuishoort. So 'n procédé verleen natuurlik groot nadruk aan die rymwoord sodat die oorgang na die volgende vers eerder vertraag as versnel word". In 'n voetnoot verwys Gräbe (1984:52) na "die verbluffend maklike wyse waarop Cloete daarin slaag om sintaktiese meerduidigheid en semantiese vermenigvuldiging te bewerkstellig deur 'n vemuftige gebruik van enjambement" en noem sy dit "'n stilistiese kenmerk" van Cloete se poësie. Die feit dat hierdie eienskap reeds ten aanvang van Cloete se oeuvre opgemerk kon word, toon hoe 'n integrale deel dit van sy idiolek is. Die ondersoek in verband met Idiolek se betekenisproduserende kernwoorde in semantiese velde (Jooste, 1989 - o.a. p. 75-82) toon dat hierdie bundel reeds ' $n$ sintese bevat van 'n digtersoeuvre wat saam met die variasie daarin getrou gebly het aan homself.

Figuur 2: Gebruiksfrekwensie van agt tiperende woorde/woordgroepe

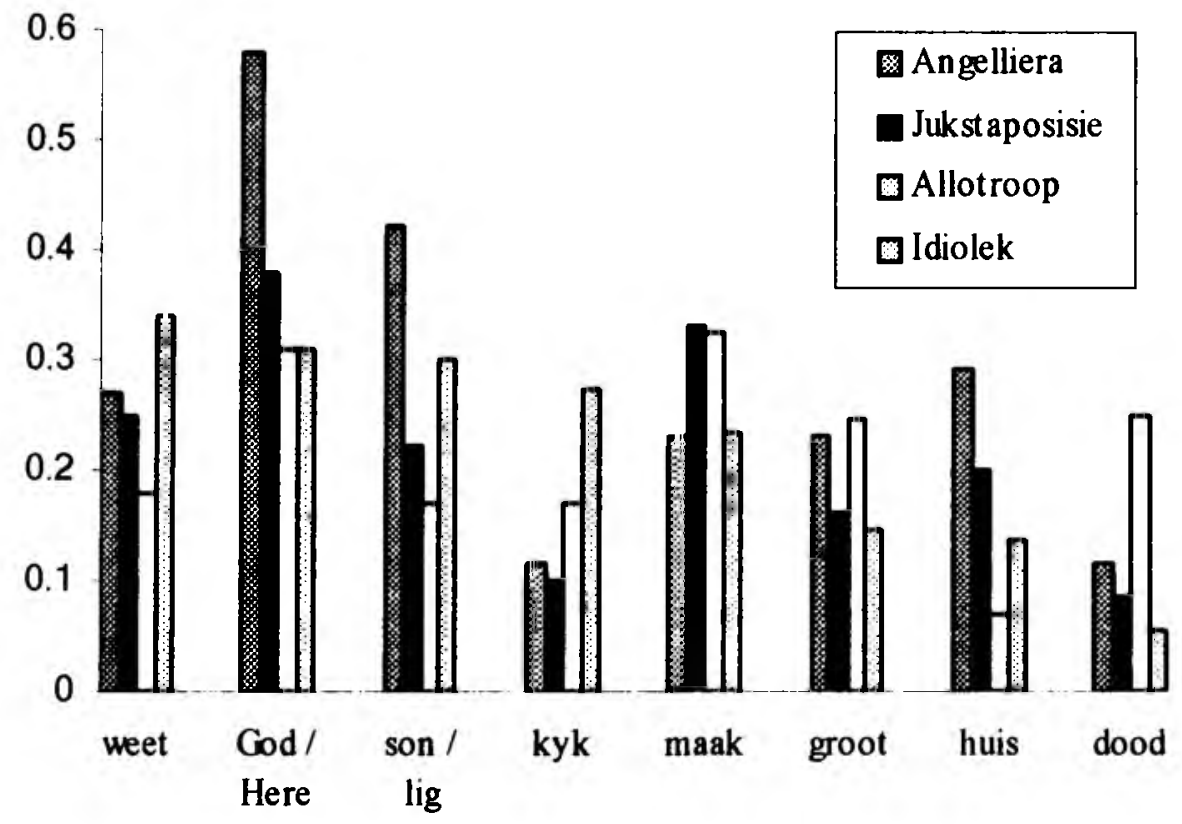




\subsection{Die visuele elemente as betekenisdraers}

Dit is Cloete se gebruik van enjambement in kombinasie met visuele tipografies-sintaktiese elemente wat opslae gemaak het in kritici se menings. Cloete se gebruik om visuele elemente as betekenisdraers in te span, is aanvanklik deur sommige kritici as onnodig bestempel. Vergelyk hiervoor Olivier (1980:12) se uitspraak waarin hy, ten spyte van die opskrif "Ryk deurdagte bundel van voorste literator" die noodwendigheid van hoofletterlose versreëls in Angelliera bevraagteken. Ook Snyman (1983:19) se andersins positiewe resepsie van Jukstaposisie verwys na Cloete se "hebbelikheid om heel dikwels oop ruimtes in plaas van leestekens te gebruik" en hy noem dit 'n "tipografiese spel wat die leesproses hortend laat verloop sonder dat dit werklik sinvol bydra tot die volledigheid van die teks".

Die teendeel hiervan, naamlik dat die bladspieël onontbeerlik is vir die interpretasie van 'n Cloete-teks, is deur 'n koerantberig gedemonstreer (vgl. Jooste, 1989:343). In dié berig is foutiewelik geen rekening gehou met die betekenis van Cloete se bladspieëlsintaksis nie. Die gedig was daarom grootliks onverstaanbaar.

Bladspieëlsintaksis is een van die patroonmatighede van Cloete se poësie wat integraal deel vorm van sy verse. Soos Cloete se konsekwente aktivering van rympatrone (horisontaal, vertikaal en diffuus) kan ook die ander visuele elemente wat hy semantiseer, teruggevoer word tot 'n stelling van Stutterheim wat hy onderskryf in sy glossariumlemma oor visuele elemente (Cloete, 1992:572): "die skrif druk elemente uit 'die in het auditieve vlak geen correlaten hebben'". Cloete se uitgangspunt is dus dat die bladspieël 'n "semantiese dimensie" aan woorde toevoeg. Hy stel dit in reeds genoemde lemma dat leestekens "oor die algemeen 'n baie sterk visuele waarde het". Ten spyte daarvan doen hy dikwels afstand van leestekens in sy poësie om 'n voor die hand liggende rede: sy ingesteldheid op meerduidigheid en samewerking van alle poëtiese elemente saam met sy vertroue in die semantiese waarde van visuele elemente, insluitende die "wit" in die poësie.

In hierdie verband is Hambidge (1984:60) se opmerking relevant, naamlik dat ons Cloete moet lees soos die gedigte self dit aan ons voorskryf. Hambidge sê verder dat die wit spasies "'n opheffing van die finale betekenis" impliseer (1984:60) en sy sien die "literêrheid" van Cloete se bundels (op daardie stadium het slegs Angelliera en Jukstaposisie bestaan) as 'n "ver-woord/be-skryf" van 'n poststrukturalistiese uitgangspunt. Volgens Hambidge (1984:60) begin en eindig die teks in Cloete se poësie in die taal: "die leser word dus teruggedwing na die teks wat geen finale antwoord bied nie". 
Juis dít is moontlik omdat die leser die woorde van die literêre teks in Cloete (1992:572) se terme "simultaan" voor hom het. Cloete (1992:572) begrond sy siening met "Martin Heidegger se uitspraak in Holtzwege dat die woord in die literêre teks durend aanwesig bly en nie in die tyd verbygaan met die verloop van die kommunikasie soos dit met ander tekste of in die gesprek die geval is nie." Juis omdat 'n leser nie sintagmaties hoef te lees nie, maar paradigmaties, en hy "sinchronies lees en tot insigte kom waartoe die ouditiewe konkretisering hom nie kan lei nie" (Cloete, 1992:573), is die moontlikhede van meerduidigheid wat die weglaat van leestekens bied so integraal deel van Cloete se poësie. Dit vind by uitstek neerslag in die bundel Idiolek.

Hoewel die glossarium van literatuurwetenskaplike terme, waarin Cloete 'n lemma oor die "visuele momente in die literatuur" (Cloete, 1992) geskryf het, eers teen die einde van 1988 gereed was vir publikasie, het Cloete reeds hierdie siening in 1984 genoteer. Die datum waarop die manuskrip daarvan geskryf is, val in die sentrum van die tydperk 1980-1986 waarin Cloete se eerste vier digbundels verskyn het. In die betrokke lemma slaan hy die visuele elemente in die literatuur besonder hoog aan en na sy mening is die "konkrete kommunikatiewe bydrae wat die gedrukte voorkoms tot die geheel maak" vir hom van bepalende belang. Hoewel Cloete (1992:572) aanvaar dat taal natuurlikerwys 'n ouditiewe kommunikasiemiddel" is, wys hy daarop dat ons moet aanvaar "dat die letterkundige werk in die moderne tyd, na die uitvinding van die boekdnukkuns, grotendeels vir die lesende oog geskryf word en nie vir die oor in orale vorm bestem is nie". So 'n uitspraak loën die kritiek van byvoorbeeld Snyman (1982) dat "Cloete se gewoonte om sinne in die middel van reëls te skei met oop spasies 'n 'maniërisme' is". Dit is immers juis die visuele pouseringe in Cloete se poësie wat fundamenteel vir die interpretasie daarvan is.

Die "groter spasies tussen sinne en sinsdele waar 'n mens normaalweg interpunksie sou verwag het" (Nienaber, 1983:57), kan in Idiolek (by herhaling) deur die bestudering van teksvariante as doelbewuste procédé van Cloete uitgewys word (Jooste, 1989:257-305). Die enkele gevalle waar konvensionele interpunksie wel voorkom, is $\mathrm{m}$ ldiolek, soos in vorige bundels, op funksionaliteit gerig. Roos (1983:6) het in hierdie verband ten opsigte van Jukstaposisie gewys op "seldsame gevalle waar konvensionele interpunksie voorkom", en daarin 'n epiese trant geresepteer: dit is "asof 'n verhaalagtige toon insluip ... byna of ' $n$ verteller aan die woord is en in kontras met die 'stroming' van die liriese poësie nou formeel kommunikeer".

Met die verskyning van Allotroop was dit moontlik om progressie in die funksionering van poētiese wit af te lei. Dit wat Brink (1983:31) as "ruimtelike 
periodisering" in Jukstaposisie getipeer het, is so deel van Idiolek dat 'n gedig soos "Nuwe bedeling" (Cloete, 1986b:30-31) skerp opval en as funksionele interne afwyking in Cloete se idiolek getipeer kan word. Venter (1988:96) bevestig hierdie funksionele aanpassing van die visuele beeld in Cloete se verse in haar bespreking van "Hommage à C.M. van den Heever". Sy toon onder andere hoe die lang verse van die eerste strofe "opvallend van die kort verse van die tweede strofe" verskil omdat die korter verse by die "nou situasie" hoort en in kontras staan met die "likwiede, daardie vervloeiende" soos Cloete die verse van Van den Heever in Kaneel getipeer het. Venter bevestig in der waarheid die wisselwerkende literator-digterskap van Cloete hierin.

'n Visueel-verwante aspek van Cloete se poësie wat sedert Angelliera die aandag trek, is die eie-aardige sintaksis daarvan. Snyman (1980) verwys byvoorbeeld na die "kriptiese sintaksis" as kenmerk van hierdie bundel. Visagie (1986:244) wys in Angelliera op 'n "spanning tussen sin en versreël deurdat die sintaktiese samehorende woorde in verskillende versreëls geplaas word". Pretorius (1984:83) noem Cloete se kenmerkende sintaktiese procédé in Jukstaposisie "apokoinou" en tipeer hierdie verskynsel as "'n vormkenmerk wat tegelyk liries en intellektueel is". Ook hierin is daar 'n verskuilde duiding van die jukstaposisionele aard van Cloete se literator-digterskap wat so prominent neerslag vind in Idiolek.

'n Ander ondersoeker van die poësie van Cloete, Visagie (1986:244), noem apokoinou "een van die opvallendste verstegniese kenmerke in Angelliera en Jukstaposisie". Hierdie sintaksis is so deel van Cloete se poësie dat dit in Allotroop en Idiolek weinig of geen bespreking van resensente ontlok het nie. Ook die tegniek van inversie, wat deur byvoorbeeld Visagie (1986:244) in die eerste twee bundels as funksionele verandering van woordorde waargeneem is, word later nie eens meer deur lesers genoem nie, hoewel dit onmiskenbaar deel vorm van die sintaksis van die verse in laasgenoemde twee bundels.

\subsection{Die leksikale komponent van Cloete se poësie}

Cloete se woordontginning het positiewe sowel as negatiewe reaksie van lesers ontlok. Johl (1980:9) verwys na die taal in Angelliera as "'n ruie vag van vlegsels en knope met die heerlikste verrassings ingebind". Hy beskou dit as "kundige poësietaal" (weer eens 'n duiding op literator-digterskap) en hy verwys na Cloete se vermoë om te suggereer en atmosfeer met die taal te skep. Ook Pretorius (1981:81) verwys na die "evokatiewe woordeskat" van 'n gedig van Cloete en dui 'n aantal vindingryke nutskeppinge aan - 'n aanvanklike resepsie wat deurgetrek kan word tot in Cloete se vierde bundel. 
Teenoor Johl en Pretorius se positiewe resepsie van die leksikale komponent van Cloete se poësie, kla Brink (1983:31) in verband met Jukstaposisie, oor "die voorliefde vir tegniese 'wetenskaplike' en veral Grieks-geïnspireerde jargon ... 'n oormaat aan herhaling ... die selfbewuste 'verliterêrde". Laasgenoemde word deur Brink verklaar as ' $n$ "soort vertonerige erudisie wat nie 'n eenvoudige woord sal kies as daar 'n jawbreaker voorhande is nie". Brink (1985:17) kontinueer hierdie siening (ten spyte van 'n andersins besonder positiewe resensie soos ook dié van Jukstaposisie was) in verband met Allotroop en verwys na "'n neiging om te estetiserend-literêr te wil 'doen', onder andere deur 'n uitstal van 'groot woorde"'. In teëstelling hiermee verwys Visagie (1986:241) na die "tweeledigheid" in Cloete se taalgebruik, naamlik dat hy van "spreektaal" sowel as "vak- en wetenskaplike terminologie" gebruik maak. In die ondersoek van woordfrekwensies wat vroeër vermeld is, kon immers aangetoon word hoe die gewone woord 'n hoë gebruiksfrekwensie in die genoemde vier digbundels geniet en in semantiese velde meerduidigheid verkry. Ten spyte van heelwat vak- en wetenskaplike terminologie sowel as aktualiteitsbenaminge is die oorwig juis die "gewone" woord wat kundig kreatief ingespan word.

Die "rustige spel met die Afrikaanse woord waar hy soms die neutrale woord net so 'n knakkie kan gee en daarmee 'n nuwe wêreld kan oopmaak" (Du Plessis, 1982:4), is nog aan die orde in Idiolek maar dan met die klem op tipering van die digterswerksaamheid teenoor die werkinge van God. Die volgende uitspraak van Spies (1983:11) in verband met Jukstaposisie kan veralgemeen word as konsensus van die meeste resensente se mening oor Cloete se leksikale vermoëns in die vier digbundels Angelliera, Jukstaposisie, Allotroop en Idiolek.

Cloete ken sy taal, hy dwing dit tot aan die uiterste grens van sêbaarheid en hy laat die leser altyd saam met hom sy taalspel beleef, maar hierdie spel ontaard nooit in blote slimmigheid nie: die spelende digter bly die singende digter.

Spies se woorde vind aansluiting by dié van Cloete self (1980b) waarin hy verklaar dat die digter die "onsêbare" wil sê "en wel in Afrikaans. Daarom soek hy 'room' vir ons uitdrukkingsmiddele". Dit motiveer nie alleen sy "kundige nuutskeppinge" nie, maar ook die "hegte inweef van terugkerende woorde, beelde en motiewe wat met mekaar gekoppel" word "om so oorkoepelende eenheid aan die bundel as geheel te gee" (Roos, 1983:6).

Dit is hierdie eienskap wat by uitstek in ldiolek aangetoon kan word en dit onderskryf Grové (1986:8) se stelling dat Cloete die "taal in sy eenvoudigste, 
maar ook in sy mees gesofistikeerde gedaante nodig het". Grové sien dit as "'n essensiële deel van die idiolek wat eie is aan elke digter van betekenis en wat by Cloete saamhang met die geloof dat God en sy wonderwerking deur elkeen op sy eie wyse ervaar word en dus op 'n eie wyse tot spreke sal kom".

Idiolek bied inderdaad 'n "astrak" van die "taaldinkversameling" wat in Cloete se poëtika en sy eerste drie digbundels ontplooi het. 'n Mens kan dit selfs saamvat in sy eie dubbelster-beeld (Cloete, 1982b:15): poëtika en poësie "roteer gepaar om dieselfde swaartepunt" van Godsverbondenheid.

\section{Bibliografie}

Baetens, J. 1987. Intertextualiteit (anders) bekeken. Spiegel der Letteren, 29(12):61-62.

Bloom, H. 1973. The Anxiety of Influence: A Theory of Poetry. New York : Oxford University Press.

Botha, M.C. 1985. Allotroop by T.T. Cloete. The Cape Times: 13, Sept. 25.

Brink, A.P. 1983. Ongetwyfeld dié digbundel van 1982. Rapport: 31, Feb. 20.

Brink, A.P. 1985. Cloete se nuwe bundel sy kragtigste. Rapport: 17, Jul. 7.

Claes, P. 1987. Bijzondere en algemene intertextualiteitstheorie. Spiegel der Letteren, 29(1-2):7-15.

Cloete, T.T. 1980a. Angelliera. Kaapstad : Tafelberg.

Cloete, T.T. 1980b. Gesprek met Leon van Nierop. (SAUK Afrikaanse diens: Skrywers en boeke, 25 Aug.)

Cloete, T.T. 1982a. Hoe om 'n gedig te ontleed. Pretoria : Academia. (Reuse Blokboek 16.)

Cloete, T.T. 1982b. Jukstaposisie. Kaapstad : Tafelberg.

Cloete, T.T. 1985. Allotroop. Kaapstad : Tafelberg.

Cloete, T.T. 1986a. Onderhoud met ' $n$ bobbejaan. Pretoria: HAUM.

Cloete, T.T. 1986b. Idiolek. Kaapstad : Tafelberg.

Cloete, T.T. 1988a. Persoonlike gesprek met outeur op $14 \mathrm{Mrt}$. Potchefstroom.

Cloete, T.T. 1988b. Persoonlike gesprek met outeur op 14 Sept. Potchefstroom.

Cloete, T.T. 1988c. Astrak uit die vier bundels tot by ldiolek. (Lesing gelewer in Sept. voor die studente van die Departement Afrikaans-Nederlands aan die Universiteit van Pretoria.) Pretoria. (Afdruk van spreker se manuskrip-notas in artikelskrywer se besit.)

Cloete, T.T. 1988d. Die boek wat laaste uitgepak word: oor die Bybel en die Afrikaanse digkuns. (Lesing gelewer in Julie op uitnodiging van die C.B. Powell-Bybelsentrum, UNISA. Pretoria.) (Ongepubliseerde notas met bladsye genommer van 19-50 in artikelskrywer se besit.) 
Cloete, T.T. 1992. Die visuele elemente in die poësie. In: Cloete, T.T., (red.) Literêre terme en teorieë. Pretoria : HAUM-Literêr.

Dorlijn, G.J. 1984. J.H. Leopold. Gedichten uit de nalatenschap. Amsterdam : Noord-Holland.

Du Plessis, H. 1982. T.T. Cloete se nuwe bundel pure genot. Die Volksblad: 4, Des. 14.

Gilfillan, F.R. 1985. Cloete-verse 'n literêre verowering. Die Burger: 18, Jul. 25.

Gräbe, I. 1981. Bespreking van Angelliera. Tydskrif vir Letterkunde, 19(2):69-77.

Gräbe, I. 1984. Kommunikasiemiddele in die poësie. In: SAVAL-kongresreferate: referate gelewer by die hoofkongres van die Suid-Afrikaanse Vereniging vir Algemene Literatuurwetenskap gehou by die Universiteit van die Witwatersrand te Johannesburg. Potchefstroom : PU vir CHO. p. 137-171.

Gräbe, I. 1985. Belangrike variasies op vorige temas. Ritsgids bylae tot Die Transvaler: 6, Jul. 4.

Grové, A.P. 1985. Allotroop een van die belangrikstes. Beeld: 8, Jul. 1.

Grové, A.P. 1986. Duidelik Cloete en profiel is skerper. Beeld: 8, Nov. 17.

Hambidge, J. 1984. Bestekopname: T.T. Cloete se Angelliera en Jukstaposisie. Standpunte, 37(1):57-63, Jun.

Hambidge, J. 1985. Moeilik om droefnis te stelp. Die Vaderland: 9, Mei 13. Hambidge, J. 1986. Die skeptiese kritikus. Standpunte, 3(2):30-35, Apr.

Hambidge, J. 1986a. Onmiskenbare poëtiese talent bevestig. Beeld: 10, Nov. 11.

Jannsen, F.A. 1984. Transcriptie. In: Bachrach, A.G.H., Van Bork, G.J., De Grève, M., Weisgerber, J., Würzner, M.H., (reds.) Moderne Encyclopedie van de Wereldliteratuur. Weesp : De Haan. 9:345.

Johl, J. 1980. Angel + lier = pyn + plesier. Die Volksblad: 9, Des. 15.

Jooste, E. 1989. Idiolek van T.T. Cloete: vers, sin en Woord in jukstaposisie. Potchefstroom : PU vir CHO. (D.Litt. proefskrif.)

Lefevere, A. 1977. Literary Knowledge: a Polemical and Programmatic Essay on Its Nature, Growth, Relevance and Transmission. Amsterdam : Van Gorcum.

Nienaber, C.J.M. 1983. Cloete en vliegtuigie op handjie. Standpunte, 36(1):56-64, Feb.

Olivier, F. 1980. Ryk deurdagte bundel deur voorste literator. Die Burger: 12, Des. 12.

Pretorius, R. 1981. Bespreking van Angelliera. Tydskrif vir Letterkunde, 19(2):77-83, Feb. 
Pretorius, R. 1984. Skouspel en Carcasonne: die 'klankdenke' in jukstaposisie. In: Viljoen, H., Gräbe, I., Jooste, E. \& Steenberg, D., (reds.) In teen die groot vergeet: ' $n$ bundel opstelle opgedra aan T.T. Cloete by geleentheid van sy sestigste verjaarsdag op 31 Mei 1984. Potchefstroom : PU vir CHO. p. 79-92.

Pretorius, R. 1987. Kanttekeninge by T.T. Cloete se vierde digbundel. Tydskrif vir Letterkunde, 25(2):27-37, Mei.

Roos, H. 1983. T.T. Cloete bevestig sy vaardighede. Beeld: 6, Jan. 17.

Snyman, H. 1980. Bespreking van Angelliera. SAUK Afrikaanse diens:

Skrywers en boeke. Des. 5. (Bandopname in besit van T.T. Cloete.)

Snyman, H. 1982. Bespreking van Jukstaposisie. SAUK Afrikaanse diens:

Skrywers en boeke. Des. 17. (Bandopname in besit van T.T. Cloete.)

Snyman, H. 1983. 'n Kaleidoskopiese reaksie van 'n gevoelige mens. Die Vaderland: 19, Feb. 24.

Spies, L. 1983. T.T. Cloete laat heelal sing. Die Burger: 11, Jan. 13.

Swanepoel, J. 1981. Poësie van verskeidenheid en verband: 'n bespreking van T.T. Cloete se Angelliera. Literator, 2(1):53-63, Feb.

Van Dale, J.H. 1977. Nieuw handwoordenboek der Nederlandse taal. 's Gravenhage : Nijhoff.

Van der Walt, M.J. 1987. Die verwerking van Bybelse materiaal in die poësie van T.T. Cloete. Pretoria. UNISA. (M.A.-verhandeling.)

Van Gorp, H. 1984. Lexicon van literaire termen. Leuven : Wolters.

Van Zyl, I. 1983. Jukstaposisie dié jaar se beste bundel. Die Suidwester: 10, Sept. 30.

Venter, I.L. 1988. Intergedigtelike verhoudings in die poësie van T.T. Cloete met Jukstaposisie as vertrekpunt. Pretoria : UP. (D.Litt. proefskrif.)

Viljoen, H.M. 1983. Jukstaposisie. (Aantekeninge uit 'n semester-seminaar, PU vir CHO.) Potchefstroom. (Ongepubliseer.)

Visagie, J.A.G. 1986. T.T. Cloete as eksponent van die moderne Afrikaanse poësie soos hy dit self gekarakteriseer het in "Die literatuur sedert sestig". Pretoria : UNISA. (M.A.-verhandeling.)

Werumeus Buning, J.W.F. 1935. Negen balladen. Asterdam : Querido. 
